\title{
Evaluasi Tata Kelola Teknologi Informasi berbasis COBIT 5 pada Badan Pendapatan Daerah Kabupaten Badung
}

\author{
Putu Hary Sinta1 , I Putu Agus Swastika ${ }^{2}$, I Gst Lanang Agung Raditya Putra
}

Address: STMIK Primakara Denpasar Bali, Program Studi SIstem Informasi, Indonesia 1,2,3

Email: harysinta@gmail.com ${ }^{1}$, masagusswastika@gmail.com², la.raditya27@gmail.com³

* Corresponding author

\begin{abstract}
Abstrak
Badan Pendapatan Daerah Kabupaten Badung Dinas Pendapatan/Pasedahan Agung Kabupaten Badung merupakan organisasi perangkat daerah yang memiliki tujuan pokok dan fungsi mengelola pendapatan daerah. Pengelolaan pendapatan daerah tersebut sebagai sumber pembiayaan daerah dalam melaksanakan pembangunan daerah. Diperlukan suatu kerangka kerja sebagai reference model, untuk memastikan kualitas tata kelola TI pada Badan Pendapatan Daerah Kabupaten Badung. Audit Tata kelola teknologi informasi (TI) diperlukan agar sesuai dengan kerangka kerja tata kelola $\mathrm{TI}$ dan mengacu pada standar Control Objective for Information and Related Technology (COBIT). Kerangka kerja COBIT ini memberikan solusi dalam menerapkan model tata kelola TI. Penelitian ini fokus pada domain EDM 4, APO 1, APO 7, BAI 4, BAI 9, DSS 1, MEA 1. Menghasilkan temuan bahwa Tata Kelola Teknologi Informasi pada Badan Pendapatan Daerah Kabupaten Badung telah melaksanakan hampir semua katifitas TI dan mempunyai tingkat kematangan 3 (Established).
\end{abstract}

Keywords Audit Tata Kelola Teknologi Informasi, COBIT 5, EDM 4, APO 1, APO 7, BAI 4, BAI 9, DSS 1, MEA 1.

\section{Latar Belakang}

Perkembangan sistem teknologi informasi menyebabkan perubahan-perubahan peran mulai dari peran efisiensi, efektivitas sampai pada peran strategic. Di era globalisasi ini perkembangan teknologi informasi semakin canggih. Teknologi informasi (TI) tidak hanya difungsikan sebagai pendukung (support) tapi menjadi bagian atau penentu kesuksesan sebuah organisasi atau instutusi. Pengelolan TI diarahkan untuk peningkatan kinerja suatu organisasi dan merupakan tanggung jawab seluruh manajemen dalam organisasi. Penerapan TI telah menyebar hampir ke seluruh aspek kehidupan, salah satunya pada layanan pemerintahan Badan Pendapatan Daerah Kabupaten Badung. Penerapan TI pada kantor pemerintahan sangatlah penting untuk mengoptimalkan kinerja agar mempermudah pelayanan dan memberikan kenyamanan bagi setiap masyarakat yang akan melakukan kewajiban. Walaupun penerapan tersebut belum optimal, banyak hal yang telah dilakukan untuk mengoptimalkannya, salah satunya dengan cara melakukan audit teknologi informasi pada suatu Kantor Pemerintahan. Badan Pendapatan Daerah Kabupaten Badung yaitu merupakan Pusat Pemerintahan yang berada di Kabupaten Badung. Dalam pelayanan Badan Pendapatan Daerah Kabupaten Badung telah menerapkan TI menggunakan sistem SISMIOP (Sistem Informasi dan Manajemen Objek Pajak). Sistem SISMIOP ini sudah terintegrasi ke setiap bagian. Badan Pendapatan Daerah Kabupaten Badung menggunakan jaringan LAN (Local Area Network) atau jaringan lokal sehingga dapat menjamin keamanan data yang dimiliki oleh Badan Pendapatan Daerah Kabupaten Badung. Namun walaupun telah menggunakan sistem yang sudah terintegrasi dengan baik, akan tetapi masih terdapat beberapa kendala di Badan Pendapatan Daerah Kabupaten Badung. Salah satu framework yang bisa menganalisis evaluasi tata kelola teknologi informasi yaitu dengan menggunakan COBIT. COBIT 5 adalah versi terbaru dari framework COBIT ISACA yang menyediakan

Program Studi Teknik Informatika

Universitas Prima Indonesia (UNPRI) Medan 
penjabaran bisnis secara end-to-end dari tata kelola teknologi informasi perusahaan untuk menggambarkan peran utama dari informasi dan teknologi dalam menciptakan nilai perusahaan. [9] Berdasarkan penelitian-penelitian sebelumnya, dapat disimpulkan bahwa COBIT 5 merupakan standar terbaru untuk proses tata kelola teknologi informasi yang mampu membantu suatu organisasi atau isntansi untuk mengelola, mengembangkan, dan mempertahankan aset yang dimilikinya serta mampu membantu proses audit, tata kelola, dan manajemen teknologi informasi di organisasi atau instansi tersebut.

Penelitian ini dilakukan bertujuan membuat laopran hasil audit tata kelola teknologi informasi berdasarkan kerangka kerja COBIT (Control Objectives for Information and Related Technologies) dengan studi kasus di Badan Pendapatan Daerah Kabupaten Badung.

\section{Landasan Teori}

\subsection{Tata Kelola TI (IT Governance)}

Menurut Swastika (2015), Tata kelola TI (IT Governance) adalah wewenang dan tanggung jawab secara benar dalam menetapkan suatu keputusan untuk mendorongg perilaku penggunaan teknologi informasi pada perusahaan. Pentingnya manfaat IT governance tidak muncul secara tiba-tiba. Hal ini terjadi karena sebuah hal yang serius (critical) dalam operasional suatu organisasi. Penerapan TI di dalam organisasi dapat dilakukan dengan baik apabila ditunjang dengan suatu tata kelola $\mathrm{TI}$ mulai dari perencanaan sampai implementasinya. [7]

Menurut Jogiyanto dan Abdillah (2011), mendefinisikan tata kelola TI. Struktur system tata kelola $\mathrm{TI}$ terdiri atas komponen-komponenyang membangun system tata kelola TI, yaitu: aktiva manusia, archetype, kendali dan regulasi. Dalam konteks ini, manusia termasuk ke dalam system tata kelola TI, karena manusia merupakan komponen yang mer penting dalam merancang, $m 8$ buat keputusan, melaksanakan dan mengevaluasi system tata kelola TI. Kerangka definisi tata kelola TI dapat dilihat pada gambar. [13]

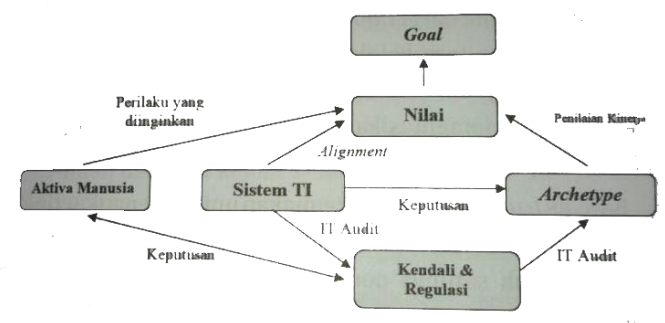

Gambar 2.1 Kerangka Definisi Sistem Tata Kelola TI (Jogiyanto dan Abdillah 2011) [13]

\section{$2.2 \mathrm{COBIT}$}

Swatika, 2015 menyatakan COBIT (Control Objectives for Information and Related Technology) merupakan kerangka kerja yang menyediakan solusi untuk tata kelola teknologi informasi melalui domain, proses, tujuan, kegiatan, model kematangan, dan struktur yang logis dan teratur. Kerangka ini dapat membantu optimalisasi investasi yang berkaitan dengan teknologi informasi, menjamin penyimpanan layanan, dan memberikan alat ukur atau standar yang efektif untuk kepentingan manajemen dalam mengambil keputusan dalam organisai. Target pengguna dari framework COBIT adaah organisasi atau perusahaan dari berbagai latar belakang dan para profesional external assurance. Secara manajerial target pengguna COBIT adalah manajer, pengguna dan profesional $\mathrm{TI}$, serta pengawas dan pengendali profesional. [7]

\subsection{COBIT 5}

COBIT 5 adalah versi terbaru dari Framework COBIT ISACA yang menyediakan penjabaran bisnis secara end-to-end dari tata kelola teknologi informasi perusahaan untuk menggambarkan peran utama dari informasi dan teknologi dalam menciptakan nilai perusahaan.

\subsection{Domain COBIT 5}

COBIT 5 membagi proses tata kelola dan manajemen $\mathrm{TI}$ suatu perusahaan atau organisasi menjadi dua area proses utama, yaitu:

1) Tata kelola, memuat lima proses tata kelola, dimana akan ditentukan praktik-praktik dalam setiap proses evaluate, direct, and monitor (EDM).

2) Manajemen, memuat empat domain, sejajar dengan area tanggung jawab dari plan, build, run, and monitor (PBRM), dan menyediakan ruang lingkup TI yang menyeluruh dari ujung ke ujung (end-to-end). Domain ini merupakan evolusi dari domain dan struktur proses dalam COBIT 4.1, yaitu:

a) Align, Plan, and Organize (APO). Domain ini meliputi penyelarasan, perencanaan, dan pengaturan agar Tl dapat berkontribusi untuk mecapai tujuan bisnis.

b) Build, Acquire and Implement (BAI). Domain ini meliputi membangun, memperoleh, dan mengimplementasikan sistem yang mendukung proses bisnis.

c) Delivery, Service and Support (DSS). Domain ini meliputi mengirimkan, layanan, dan dukungan

Program Studi Teknik Informatika

Universitas Prima Indonesia (UNPRI) Medan 
atau memberi pelayanan yang aktual bagi bisnis, termasuk manajemen data dan proteksi informasi yang berhubungan dengan proses bisnis.

d) Monitoring, Evaluation and Assess (MEA). Domain ini terdiri dari pengawasan, evaluasi dan penilaian manajemen tentang pengendalian proses-proses, oleh lembaga monitoring independen yang berasal dari dalam dan luar orgaisasi atau lembaga alternatif lainnya.

\subsection{ISO/IEC 15504}

ISO/IEC 15504, atau dikenal dengan SPICE (Software Process Improvement and Capability dEtermination) adalah suatu "kerangka kerja untuk penilaian proses" yang dikembangkan bersama oleh (International Organization for Standardization) dan IEC (International Electrotechnical Commission). ISO/IEC 15504 awalnya diturunkan dari standar siklus hidup proses ISO 12207 dan digunakan sebagai dasar pembuatan Capability Maturity Model (CMM). [7]

Tingkat kapabilitas suatu proses pada model ISO/IEC 15504 memiliki nilai dari 0 (incomplete), 1 (performed), 2 (managed), 3 (established), 4 (predictable), 5 (optimizing). Menurut ISACA (2012), kegiatan penilaian membedakan antara penilaian untuk level 1 dengan level yang lebih tinggi. Hal ini dilakukan karena level 1 menentukan apakah suatu proses mencapai tujuannya, dan oleh karena itu sangat penting untuk dicapai, dan juga menjadi pondasi dalam meraih level yang lebih tinggi. Dalam penilaian pada tiap levelnya, hasil akan diklarifikasikan dalam 4 kategori sebagai berikut:

1) $\mathbf{N}$ (Not achived/tidak tercapai). Artinya dalam katagori ini tiadk ada atau hanya sedikit bukti atas pencapaian atribut proses tersebut. Range nilai yang diraih pada kategori ini berkisar 0-15\%.

2) $\mathbf{P}$ (Partially achived/ tercapai sebagain). Pada kategori ini terdapat beberapa bukti mengenai pendekatan dan beberapa pencapaian atribut atas proses tersebut. Range nilai yang diraih pada kategori ini berkisar $15-50 \%$.

3) L (Largely achived/ secara garis besar tercapai). Dalam kategori ini terdapat bukti atas pendekatan sistematis dan pencapaian secara signifikan atas proses tersebut, meski mungkin masih ada kelemahan yang tidak signifikan. Range nilai yang diraih pada kategori ini berkisar $50-85 \%$.

4) $\mathbf{F}$ (Fully achived/tercapai penuh). Jika terdapat bukti atas pendektan sistematis dan lengkap dan pencapaian penuh atas atribut diklarifikasi dalam kategori ini. Tidak ada kelemahan terkait atribut proses tersebut. Range nilai yang diraih pada kategori ini berkisar 85-100\%. [7]

ISO/IEC Measurement Scale

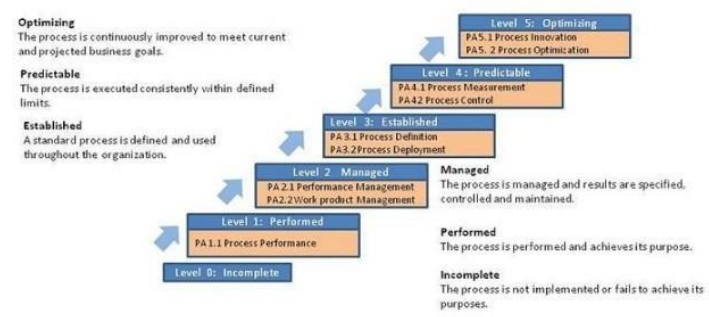

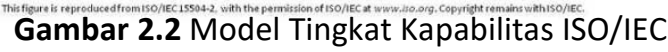
15504 (http://www.isaca.org) [10]

\section{Metode}

\subsection{Metode Penelitian}

Penelitian ini adalah penelitian kualitatif yang menyimpulkan bahwa metode penelitian kulitatif adalah metode penelitian yang berlandaskan pada filsafat postpositivisme, digunakan untuk meneliti pada kondisi obyek yang alamiah, (sebagai lawannya eksperimen) dimana peneliti adalah sebagai instrument kunci, pengambilan sampel sumber data dilakukan secara purposive dan snowbaal, teknik pengumpulan dengan trianggulasi (gabungan), analisis data bersifat induktif/kualitaif, dan hasil penelitian kualitatif lebih menekankan makna dari pada generalisasi.

Jenis pendekatan yang digunakan adalah pendekatan studi kasus. Penelitian studi kasus berorientasi untuk memahami, menggali, dan menafsirkan arti dan peristiwa-peristiwa, dan hubungan dengan orang-orang yang biasa dalam kasus tertentu. Ini biasa disebut dengan penelitian kualitatif dengan menggunakan pengamatan terhadap fenomenafenomena atau gejala-gejala sosial yang alamiah yang berdasarkan kenyataan lapangan (empiris). Dalam penelitian ini kasus yang diteliti adalah evaluasi tata kelola teknologi informasi khususnya dalam penerapan layanan sistem informasi di Badan Pendapatan Daerah Kabupaten Badung. Evaluasi layanan sistem informasi di Badan Pendapatan Daerah Kabupaten Badung menggunakan framework COBIT 5 pada domain EDM4 (memastikan pengoptimalan sumber daya), APO1 (mengelola kerangka kerja manajemen TI), APO7 (mengelola sumber daya manusia), BAl4 (mengelola ketersediaan dan kapasitas sumber daya), BAI9 (mengelola aset perusahaan), DSS1 (mengelola operasi), MEA1 (monitor, evaluasi, dan penilaian kinerja dan kesesuaian). Alur proses audit sistem informasi menggunakan COBIT 5 dapat dilihat pada gambar dibawah 


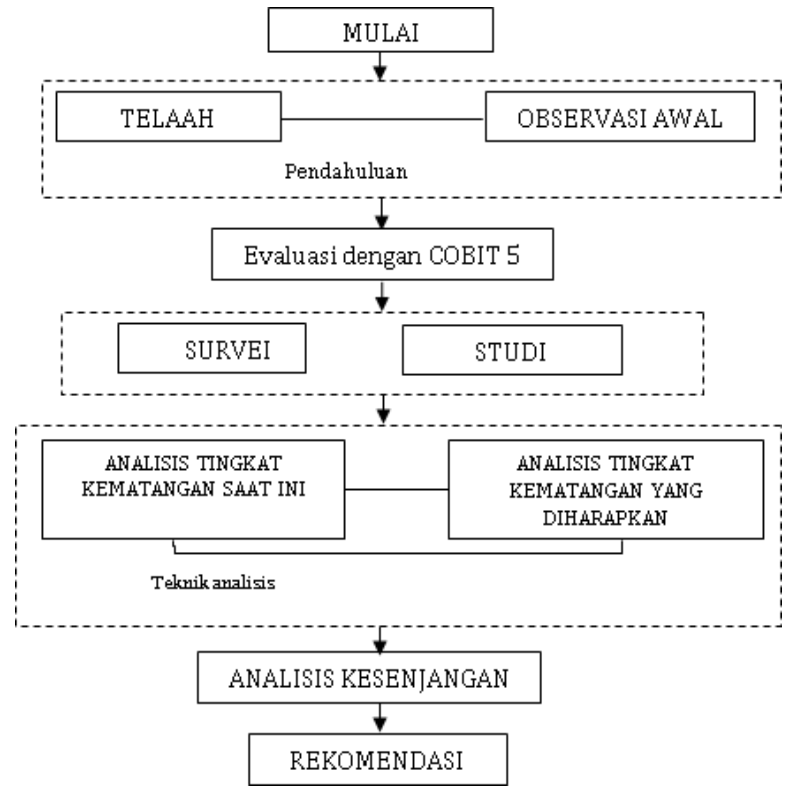

Gambar 3.1 Alur Proses Audit Sistem Informasi COBIT 5.

\subsection{Objek Penelitian}

Penelitian ini dilakukan di Badan Pendapatan Daerah Kabupaten Badung. Evaluasi tata kelola teknologi informasi menggunakan framework COBIT 5 pada domain EDM4 (memastikan pengoptimalan sumber daya), APO1 (mengelola kerangka kerja manajemen $\mathrm{TI}$ ), APO7 (mengelola sumber daya manusia), BAI4 (mengelola ketersediaan dan kapasitas sumber daya), BAI9 (mengelola aset perusahaan), DSS1 (mengelola operasi), MEA1 (monitor, evaluasi, dan penilaian kinerja dan kesesuaian).

\subsection{Model Evaluasi}

Model evaluasi pada penelitian ini menggunakan framework COBIT 5, karena menyediakan petunjuk yang lebih detail yang dibutuhkan oleh pengguna sebagai referensi serta mudah dipahami dalam operasional TI. Domain yang diteliti adalah EDM4, APO1, APO7, BAI4, BAI9, DSS1, dan MEA1. Pemilihan domain berdasarkan analisis penulis dari hasil wawancara yang telah dilakukan menunjukkan bahwa domain tersebut terkait dengan masalah yang terdapat pada layanan sistem informasi Badan Pendapatan Daerah Kabupaten Badung.

Setelah melakukan evaluasi selanjutnya akan dilakukan penilaian berdasarkan model ISO/IEC 15504 untuk mengetahui tingkat kematangan tata kelola teknologi informasi di Badan Pendapatan Daerah Kabupaten Badung untuk medapatkan rekomendasi yang selanjutnya dilakukan perbaikan sehingga mampu efisien. [7]

mewujudkan layanan yang bermafaat, efektif, dan

\subsection{Model Pengumpulan Data}

Objek penelitian diarahkan pada pendapat, persepsi, tanggapan yang terkait dengan pengelolaan TI khusunya penerapan layanan sistem informasi di Badan Pendapatan Daerah Kabupaten Badung, yang dilandasi dengan model framework COBIT 5. Data kuantitatif, yaitu berupa pilihan terhadap pertanyaan atau pernyataan yang di kuantifikasikan dengan skala tingkat model kapabilitas ISO/IEC 15504.

\section{Instrument Penelitian}

Instrumen utama dalam penelitian kualitatif ini adalah peneliti yang dibantu dengan alat bantu pengumpul data berupa daftar pertanyaan (kuesioner), pedoman wawancara, dan buku catatan Hubungan antara masalah, sumber data, metode, dan instrument.

\section{Teknik Pengumpulan Data}

Pengumpulan data dilakukan dengan teknik survei, wawancara, dan studi dokumentasi (Riduwan, 2007). Untuk mendapat data yang akurat dilakukan teknik triangulasi metode pengumpulan data, yaitu pengumpulan informasi yang sama dengan metode yang berbeda, dan pengumpulan informasi dengan metode yang sama pada informan atau sumber data yang berbeda.

\section{Survei}

Survei adalah pengambilan data yang dilakukan melalui pengamatan langsung terhadap suatu gejala atau pengumpulan informasi, baik dari populasi besar maupun kecil, dengan menggunakan angket atau kuesioner.

\section{Kuesioner}

Kuesioner dalam penelitian ini dirancang untuk mengetahui tingkat kematangan tata kelola teknologi informasi dalam pelayanan sistem informasi di Badan Pendapatan Daerah Kabupaten Badung, dengan melihat tanggapan pengguna dan pembuat keputusan. Penyebaran kuesioner melibatkan semua pihak di Badan Pendapatan Daerah Kabupaten Badung yang terkait dengan pengguna dan pengelola TI. Kuesioner berisi pertanyaan-pertanyaan sesuai kerangka kerja COBIT 5 pada aktivitas sub-domain EDM4, APO1, APO7, BAI4, BAI9, 28 dan MEA1. Masing-masing penilaian mem...... ot nilai antara 0 sampai dengan 5 sesuai dengan model kapabilitas ISO/IEC 15504.

\section{Wawancara}

Dalam penelitian ini pengumpulan data melalui wawancara. Wawancara dilakukan terhadap responden kuesioner dengan metode interview dimana penulis mengajukan pertanyaan dan responden memberikan jawaban terkadang jawaban hanya membutuhkan jawaban ya atau tidak. 


\section{Studi Dokumen}

Iskandar, 2008 menyatakan studi dokumentasi ditujukan untuk memeroleh data langsung dari tempat penelitian, meliputi buku-buku yang relevan, peraturan-peraturan, laporan kegiatan, jurnal, foto-foto, film dokumenter, dan data yang relevan.

\subsection{Teknik Analisis Data}

1. Analisis Kematangan saat ini (as-is)

Berdasarkan data hasil survei kuesioner, wawancara, dan studi dokumen analisis yang dilakukan pada tahap ini adalah analisis untuk menilai tingkat kematangan tata kelola teknologi informasi pada aktivitas domain EDM4, APO1, APO7, BAI4, BAI9, DSS1, dan MEA1 saat ini (as-is). Pada tahap ini penulis melakukan penilaian terhadap masing-masing aktivitas berdasarkan hasil kuesioner seluruh responden. Setelah masing-masing aktivitas memperoleh nilai selanjutnya penulis menggabungkan seluruh nilai aktivitas dan mencari rata-rata untuk mendapatkan tingkat kematangan saat ini (as-is) pada tiap domain.

2. Analisis Tingkat Kematangan yang diharapkan (to-be)

Target atau harapan kematangan proses $\mathrm{TI}$ adalah kondisi ideal tingkat kematangan aktivitas yang diharapkan, yang akan menjadi acuan dalam model tata kelola TI sistem informasi di Badan Pendapatan Daerah Kabupaten Badung. Berdasarkan hasil wawancara, harapan kematangan proses TI ditentukan dengan melihat lingkungan internal di Badan Pendapatan Daerah Kabupaten Badung seperti visi dan misi yang sudah diterapkan, maka dapat ditetapkan bahwa untuk dapat mendukung pencapaian tujuan Badan Pendapatan Daerah Kabupaten Badung setidaknya tingkat kematangan yang dilakukan harus mencapai level 5 (optimizing). Kesenjangan antara yang diperoleh saat ini dengan yang dituju merupakan indikator dalam rumusan rekomendasi perbaikan tata kelola teknologi informasi.

3. Analisis Kesenjangan

Setelah tingkat kematangan tata kelola teknologi informasi untuk saat ini (as-is) dan tingkat kematangan tata kelola teknologi informasi yang diharapkan (to-be) diperoleh, penulis melakukan analisis kesenjangan dengan cara membandingkan masing-masing aktivitas tingkat kematangan tata kelola teknologi informasi yang diharapkan (to-be) dengan tingkat kematangan tata kelola teknologi informasi saat ini (as-is). Dari perbandingan tingkat kematangan tersebut diperoleh aktivitas mana yang tidak sesuai dengan tingkat kematangan yang diinginkan selanjutnya dilakukan perbaikan terhadap aktivitas yang tidak sesuai tersebut menuju tingkat kematangan yang diharapkan (level 5optimizing). Rekomendasi perbaikan diperoleh dari hasil analisis yang dilakukan terhadap tingkat kematangan saat ini dan tingkat kematangan yang diharapkan. Beberapa rekomendasi diambil dari sub domain framework COBIT 5 dan disesuaikan dengan strategi dan kemampuan di Badan Pendapatan Daerah Kabupaten Badung, rekomendasi tersebut diharapkan mampu memberikan hasil yang maksimal dalam pengelolaan teknologi informasi. Pada tahapan akhir penulis menyimpulkan hasil penelitian yang diperoleh. Kesimpulan yang diperoleh memuat bagaimana kondisi tata kelola teknologi informasi dalam layanan sistem informasi di Badan Pendapatan Daerah Kabupaten Badung dan kondisi tata kelola teknologi informasi yang diharapkan sebagai acuan perbaikan dan strategi perbaikan bagi instansi untuk mencapai kondisi yang diharapkan.

\section{Pembahasan Hasil Penelitian}

Dilakukan analisis data untuk mengetahui tingkat kematangan tata kelola teknologi informasi pada Badan Pendapatan Daerah Kabupaten Badung dengan menggunakan framework COBIT 5. Data yang diolah ini diperoleh dari hasil wawancara, kuesioner dan studi dokumen di Badan Pendapatan Daerah Kabupaten Badung. Data tersebut akan diolah menggunakan COBIT 5 dan penilaiannya dilakukan menggunakan ISO/IEC 15504 untuk mengetahui tingkat kematangan tata kelola teknologi informasi di Badan Pendapatan Daerah Kabupaten Badung. Pada tahap awal peneliti melakukan observasi awal serta menelaah masalah-masalah yang terjadi dengan melakukan wawancara, yaitu selanjutnya dilakukan evaluasi pemilihan domain kerangka kerja COBIT 5 yang terkait dengan masalah yang terjadi pada Badan Pendapatan Daerah Kabupaten Badung. Pada tahap kedua setelah mendapatakan domain COBIT 5 menjadi item kuesioner, peneliti melakukan survey menggunakan kuesioner yang telah dibuat ditujukan kepada pemangku atau stakeholder selaku responden, kemudian dari kuesioner tersebut akan dianalisis untuk mengetahui tingkat kematangan saat ini dan dikuatkan dengan studi dokumen. Studi dokumen ini bertujuan untuk mengetahui bahwa proses yang ada telah benar meraih level tersebut. Selanjutnya, akan dilakukan analisis kesenjangan dengan membandingkan level antara tingkat kematangan yang diharapkan dengan tingkat kematangan saat ini. Dari hasil perbandingan ini disebut jarak GAP, yang nantinya akan diberikan rekomendasi perbaikan oleh peniliti kepada Badan Pendapatan Daerah Kabupaten Badung. Badan Pendapatan Daerah Kabupaten Badung bertempat di Pusat Pemerintahan Mangupraja Mandala yang beralamat di Jalan Raya Sempidi - Badung Bali.

\subsection{Identifikasi Proses Domain COBIT 5}

Dalam tahap ini peneliti menentukan proses domain dan sub domain pada COBIT 5 terkait dengan masalah yang

Program Studi Teknik Informatika

Universitas Prima Indonesia (UNPRI) Medan 
ada di Badan Pendapatan Daerah Kabupaten Badung. Domain dan sub domain akan ditampilkan pada tabel berikut:

\begin{tabular}{|l|l|}
\hline Domain Proses & Deskripsi Proses \\
\hline EDM 4 & $\begin{array}{l}\text { Memastikan pengoptimalan sumber } \\
\text { daya }\end{array}$ \\
\hline APO 1 & Mengelola kerangka kerja manajemen \\
\hline APO 7 & Mengelola sumber daya manusia \\
\hline BAI 4 & $\begin{array}{l}\text { Mengelola ketersediaan dan kapasitas } \\
\text { sumber daya }\end{array}$ \\
\hline BAI 9 & Mengelola aset perusahaan \\
\hline DSS 1 & Mengelola operasi \\
\hline MEA 1 & $\begin{array}{l}\text { Monitor, evaluasi, dan penilaian kinerja } \\
\text { dan kesesuaian }\end{array}$ \\
\hline
\end{tabular}

\subsection{Analisi Tingkat Kematangan}

Pada tahap ini penulis melakukan penilaian terhadap masing-masing aktivitas berdasarkan hasil penyebaran kuesioner kepada seluruh responden. Setelah masing-masing aktivitas memperoleh nilai selanjutnya penulis menggabungkan seluruh nilai aktivitas dan mencari rata-rata untuk mendapatkan tingkat kematangan saat ini (as-is) pada setiap domain. Penilaian tingkat kematangan setiap proses TI mengacu pada model ISO/IEC 15504 dan dihitung dengan rumus:

$$
\text { Maturity }=\frac{\text { Total nilai }}{\text { Jumlah soal }}
$$

\subsection{Perhitungan tingkat kematangan}

\section{Analisis kuesioner}

Berikut adalah rata-rata aktivitas proses domain EDM 4, APO 1, APO 7, BAI 4, BAI 9, DSS 1, MEA 1, yang dihitung dengan cara total skor aktivitas yang diperoleh dari jawaban kuesioner dibagi dengan jumlah responden sebanyak 71 orang. Hasil perhitungan rata-rata maturity secara keseluruhan disajikan pada tabel-tabel berikut:

\begin{tabular}{|c|c|c|}
\hline $\begin{array}{l}\text { Domain } \\
\text { Proses }\end{array}$ & Deskripsi Proses & Rata-rata \\
\hline EDM 4 & $\begin{array}{l}\text { Memastikan } \\
\text { Pengoptimalan Sumber } \\
\text { Daya }\end{array}$ & 3.49 \\
\hline APO 1 & $\begin{array}{l}\text { Mengatur Kerangka Kerja } \\
\text { dan Manajemen IT }\end{array}$ & 3.50 \\
\hline APO 7 & $\begin{array}{l}\text { Mengatur Sumber Daya } \\
\text { Manusia }\end{array}$ & 3.35 \\
\hline BAI 4 & $\begin{array}{l}\text { Mengatur Persediaan dan } \\
\text { Kapasitas Sistem }\end{array}$ & 3.30 \\
\hline BAI 9 & Mengatur Aset & 3.08 \\
\hline DSS 1 & Mengelola Operasional & 3.25 \\
\hline MEA 1 & $\begin{array}{l}\text { Memantau, Mengevaluasi, } \\
\text { dan Menilai Kinerja dan } \\
\text { Kesesuaian }\end{array}$ & 3.14 \\
\hline
\end{tabular}

\subsection{Evaluasi dan analisis dokumen}

Setelah hasil yang didapatkan dari penyebaran kuesioner selanjutnya dilakukan studi dokumen untuk memvaliadasi hasil kuesioner dengan dokumen yang ada. Analisis dokumen dilakukan dengan melihat langsung dokumen-dokumen yang terkait dengan domain proses EDM 4, APO 1, APO 7, BAI 4, BAI 9, DSS 1, MEA 1.

Dokumen yang diperoleh akan di jabarkan pada tabel di bawah ini:

\begin{tabular}{|c|c|c|}
\hline $\begin{array}{l}\text { Domain } \\
\text { Proses }\end{array}$ & Nama Dokumen & Keterangan \\
\hline EDM 4 & $\begin{array}{l}\text { Dokumen } \\
\text { pengelolaan } \\
\text { SDM }\end{array}$ & $\begin{array}{l}\text { Dokumen ini memuat } \\
\text { tentang pengeloaan dan } \\
\text { peralatan penunjang } \\
\text { sistem informasi yang } \\
\text { digunakan oleh staff dan } \\
\text { pegawai yang ada di } \\
\text { Badan Pendapatan Daerah } \\
\text { Kab. Badung }\end{array}$ \\
\hline APO 1 & $\begin{array}{l}\text { Dokumen } \\
\text { manajemen TI }\end{array}$ & $\begin{array}{l}\text { Dokumen ini memuat } \\
\text { tentang pengembangan } \\
\text { struktur } \\
\text { pengoptimalan pada divisi } \\
\text { TI pada di Badan } \\
\text { Pendapatan Daerah Kab. } \\
\text { Badung }\end{array}$ \\
\hline APO 7 & $\begin{array}{l}\text { Struktur } \\
\text { Organisasi }\end{array}$ & $\begin{array}{l}\text { Dokumen ini memuat } \\
\text { tentang struktur } \\
\text { organisasi, jabatan, jumlah } \\
\text { staff dan deskripsi } \\
\text { pekerjaan di Badan } \\
\text { Pendapatan Daerah Kab. } \\
\text { Badung }\end{array}$ \\
\hline BAI 4 & $\begin{array}{l}\text { Dokumen } \\
\text { Penilaian Kinerja } \\
\text { Sistem }\end{array}$ & $\begin{array}{l}\text { Dokumen ini berisi tentang } \\
\text { penilaian kinerja pada } \\
\text { sistem informasi pada } \\
\text { Badan Pendapatan Daerah } \\
\text { Kab. Badung }\end{array}$ \\
\hline BAI 9 & $\begin{array}{l}\text { Dokumen } \\
\text { Pengelolaan } \\
\text { Aset }\end{array}$ & $\begin{array}{l}\text { Dokumen yang mencatat } \\
\text { tentang aset yang dimiliki } \\
\text { oleh Badan Pendapatan } \\
\text { Daerah Kab. Badung }\end{array}$ \\
\hline DSS 1 & $\begin{array}{l}\text { SOP } \\
\text { Pengelelolaan } \\
\text { Operasional } \\
\text { Sistem }\end{array}$ & $\begin{array}{l}\text { Dokumen ini berisi tentang } \\
\text { standar pengelolaan } \\
\text { operasioal sistem } \\
\text { informasi yang ada pada } \\
\text { Badan Pendapatan Daerah } \\
\text { Kab. Badung }\end{array}$ \\
\hline MEA 1 & $\begin{array}{l}\text { Dokumen Audit } \\
\text { tentang Sistem } \\
\text { Informasi Badan }\end{array}$ & $\begin{array}{l}\text { Dokumen ini memuat } \\
\text { tentang hasil audit } \\
\text { mengenai sistem informasi }\end{array}$ \\
\hline
\end{tabular}




\begin{tabular}{|l|l|l|}
\hline & $\begin{array}{l}\text { Pendapatan } \\
\text { Daerah Kab. } \\
\text { Badung }\end{array}$ & $\begin{array}{l}\text { di Badan Pendapatan } \\
\text { Daerah Kab. Badung }\end{array}$ \\
\hline
\end{tabular}

Rata-rata analisis kuesioner dan analisis dokumen di jabarkan pada tabel dibawah:

\begin{tabular}{|c|c|c|c|c|}
\hline $\begin{array}{l}\text { Domain } \\
\text { Proses }\end{array}$ & $\begin{array}{l}\text { Deskripsi } \\
\text { Proses }\end{array}$ & $\begin{array}{l}\text { Rata- } \\
\text { rata }\end{array}$ & Level & Kondisi \\
\hline EDM 4 & $\begin{array}{l}\text { Memastikan } \\
\text { Pengoptimalan } \\
\text { Sumber Daya }\end{array}$ & 3.49 & 3 & Established \\
\hline APO 1 & $\begin{array}{l}\text { Mengatur } \\
\text { Kerangka Kerja } \\
\text { dan } \\
\text { Manajemen IT }\end{array}$ & 3.50 & 3 & Established \\
\hline APO 7 & $\begin{array}{l}\text { Mengatur } \\
\text { Sumber Daya } \\
\text { Manusia } \\
\end{array}$ & 3.35 & 3 & Established \\
\hline BAI 4 & $\begin{array}{l}\text { Mengatur } \\
\text { Persediaan } \\
\text { dan Kapasitas } \\
\text { Sistem }\end{array}$ & 3.30 & 3 & Established \\
\hline BAI 9 & Mengatur Aset & 3.08 & 3 & Established \\
\hline DSS 1 & $\begin{array}{l}\text { Mengelola } \\
\text { Operasional }\end{array}$ & 3.25 & 3 & Established \\
\hline MEA 1 & $\begin{array}{l}\text { Memantau, } \\
\text { Mengevaluasi, } \\
\text { dan Menilai } \\
\text { Kinerja dan } \\
\text { Kesesuaian }\end{array}$ & 3.14 & 3 & Established \\
\hline
\end{tabular}

\subsection{Hasil Tingkat Kematangan}

Hasil tingkat kematangan yang telah diperoleh dari analisis kuesioner sebelumnya kemudian akan dibandingkan dengan dokumen yanga ada sesuai dengan kategori penilaian dari ISO/IEC 15504.

Kemudian dilakukan pengelolaan lebih lanjut yang perlu ditingkatkan dan dikembangkan agar kematangan yang diharapkan pada Badan Pendapatan Daerah Kab. Badung mencapai pada level 5, melalui hasil wawancara yang dilakukan. Hubungan anatara domain proses dengan validasi dokumen dapat dilihat pada tabel dibawah:

\begin{tabular}{|c|c|c|c|c|}
\hline $\begin{array}{l}\text { Domain } \\
\text { Proses }\end{array}$ & $\begin{array}{l}\text { Deskripsi } \\
\text { Proses }\end{array}$ & $\begin{array}{l}\text { Maturi } \\
\text { ty saat } \\
\text { ini }\end{array}$ & $\begin{array}{l}\text { Validasi } \\
\text { Dokum } \\
\text { en }\end{array}$ & $\begin{array}{l}\text { Maturity } \\
\text { Diharapk } \\
\text { an }\end{array}$ \\
\hline EDM 4 & $\begin{array}{l}\text { Memastika } \\
\mathrm{n} \\
\text { Pengoptim } \\
\text { alan } \\
\text { Sumber } \\
\text { Daya }\end{array}$ & 3 & 3 & 5 \\
\hline
\end{tabular}

\begin{tabular}{|l|l|l|l|l|}
\hline APO 1 & $\begin{array}{l}\text { Mengatur } \\
\text { Kerangka } \\
\text { Kerja dan } \\
\text { Manajeme } \\
\text { n IT }\end{array}$ & 3 & 3 & 5 \\
\hline APO 7 & $\begin{array}{l}\text { Mengatur } \\
\text { Sumber } \\
\text { Daya } \\
\text { Manusia }\end{array}$ & 3 & 2 & 5 \\
\hline BAI 4 & $\begin{array}{l}\text { Mengatur } \\
\text { Persediaan } \\
\text { dan } \\
\text { Kapasitas } \\
\text { Sistem }\end{array}$ & 3 & 3 & 5 \\
\hline BAI 9 & $\begin{array}{l}\text { Mengatur } \\
\text { Aset }\end{array}$ & 3 & 2 & 5 \\
\hline DSS 1 & $\begin{array}{l}\text { Mengelola } \\
\text { Operasion } \\
\text { al }\end{array}$ & 3 & 3 & 5 \\
\hline Remata-rata & $\begin{array}{l}\text { Kerau dan } \\
\text { Kesesuaian } \\
\text { Mengevalu } \\
\text { asi, dan } \\
\text { Kenilai }\end{array}$ & 3 & 3 & 5 \\
\hline MEA 1 & 3 & $\mathbf{3}$ & \\
\hline & & 5 & \\
\hline
\end{tabular}

\subsection{Analisis Tingkat Kesenjangan}

Dari hasil tingkat kematangan diatas dapat diketahui bahwa hasil tingkat kematangan sistem informasi Badan Pendapatan Daerah Kabupaten Badung saat ini berada pada level 3 (Established) sedangkan tingkat kematangan yang diharapkan adalah level 5 (Optimizing), sehingga perlu dilakukan analisis kesenjangan supaya dapat mencapai tingkat kematangan yang diharapkan pada seluruh aktiitas yang berlangsung di Badan Pendapatan Daerah Kabupaten Badung. Hal ini sesuai dengan hasil wawancara langsung kepada Kepala Badan Pendapatan Daerah Kabupaten Badung yaitu dengan staff Sub. Bidang Pemutakhiran Data dan TI pada Bidang Data dan TI di Badan Pendapatan Daerah Kabupaten Badung. Wawancara dengan staff Sub. Bidang Pemutakhiran Data dan TI pada Bidang Data dan TI sebagai berikut:

"Setelah dilakukannya penyebaran kuesioner dan analisis terhadap kuesioner tersebut, maka akan diperoleh hasil, dan hasil tersebut merupakan tingkat kematangan tata kelola TI saat ini, bagaimana menurut bapak tentang tingkat kematangan tata kelola saat ini yang berada di Badan Pendapatan Daerah Kabupaten Badung?" 
"Menurut saya berdasarkan hasil kuesioner yang sudah disebar di Badan Pendapatan Daerah Kabupaten Badung memeperlihatkan hasil yang cukup baik, akan tetapi harapan saya kedepannya agar tata kelola teknologi informasi yang berada di Badan Pendapatan Daerah Kabupaten Badung harus ditingkatkan lebih maksimal lagi untuk mencapai tingkat kematangan yang diharapkan".

Berdasarkan hasil yang didapat dari hasil perhitungan kuesioner dan studi dokumen, masih sedikitnya belum bisa mencapai level yang diharapkan sesuai dengan wawancara diatas. Dikarenakan terdapat kesenjangan di 7 domain yang digunakan. Maka peneliti akan melakukan analisis kesenjangan dengan menggunakan tingkat kematangan saat iini dan tingkat kematangan yang di harapkan agar medapat jarak (gap). Berikut adalah tabel analisis kesenjangan.

\begin{tabular}{|l|l|l|l|}
\hline \multirow{2}{*}{$\begin{array}{l}\text { Domain } \\
\text { Proses }\end{array}$} & \multicolumn{3}{|l|}{ Tingkat Kematangan } \\
\cline { 2 - 4 } & Saat Ini & Diharapkan & $\begin{array}{l}\text { GAP } \\
\text { (diharapkan- } \\
\text { saat ini) }\end{array}$ \\
\hline EDM 4 & 3.49 & 5 & $5-3.49=1,51$ \\
\hline APO 1 & 3.49 & 5 & $5-3.49=1,51$ \\
\hline APO 7 & 3.35 & 5 & $5-3.35=1,65$ \\
\hline BAI 4 & 3.30 & 5 & $5-3.30=1,70$ \\
\hline BAI 9 & 3.08 & 5 & $5-3.08=1,92$ \\
\hline DSS 1 & 3.25 & 5 & $5-3.25=1,75$ \\
\hline MEA 1 & 3.14 & 5 & $5-3.14=1,86$ \\
\hline RATA-RATA & & $\mathbf{1 , 7 0}$ \\
\hline
\end{tabular}

Dapat dilihat dari nilai rata-rata semua domain masih sedikit belum mecapai tingkat kematangan yang diharapkan oleh Badan Pendapatan Daerah Kabupaten Badung. Hal ini dapat terlihat rata-rata jarak pada seluruh domain diatas adalah 1,70 maka perlunya sedikit rekomendasi perbaikan pada setiap domain yang digunakan. Sehingga dapat mencapai tingkat kematangan yang diharapkan yaitu pada level 5 (Optimizing). Dengan demikian kondisi dari semua domain dapat digambarkan pada diagram dibawah ini:

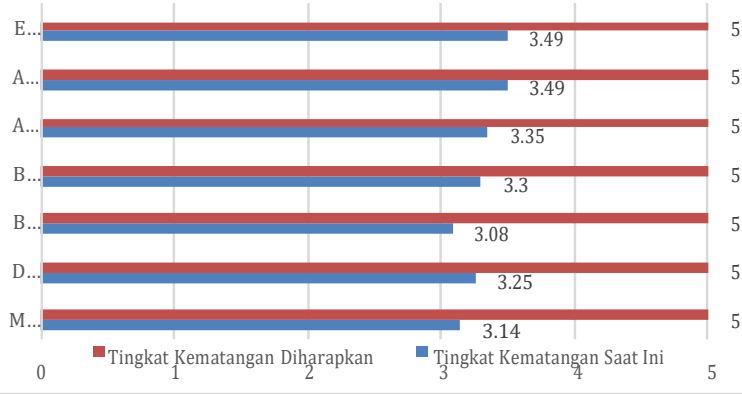

\subsection{Temuan dan Rekomendasi}

Program Studi Teknik Informatika

Universitas Prima Indonesia (UNPRI) Medan
1. Domain APO 1 Mengatur Manajemen $\mathrm{TI}$ dan domain APO 7 Mengatur Sumber Daya Manusia. Pada domain APO 1 dan APO 7 tingkat kematangan saat ini yaitu berada level 3 (established). Pengelolaan sumber daya manusia pada Badan Pedapatan Daerah Kabupaten Badung sudah dilakukan dengan baik sesuai dengan yang diharapkan oleh perusahaan, walaupun terdapat beberapa staff yang bertugas pada penggunaan sistem informasi belum memiliki kompetensi yang sesuai. Untuk menghindari kesalahan ini terulang perlu adanya rekomendasi perbaikan yaitu sebagai berikut:

a) Melakukan pelatihan secara intens oleh pihak IT di Badan Pendapatan Daerah Kabupaten Badung kepada admin yang menjalankan sistem SISMIOP (Sistem Informasi dan Manajemen Objek Pajak) tersebut. Sehingga resiko kesalahan input data wajib pajak dapat diminimalisasi dan juga bisa memaksimalkan segala kemudahan yang diberikan dan pada akhirnya target penerimaan data tercapai.

b) Dibuatkan sistem yang informasi dengan user interface yang mudah digunakan (user friendly) agar dapat memudahkan staff yang bertugas dalam mengoperasikan sistem informasi di Badan Pendapatan Daerah Kabupaten Badung. Serta melaksanakan sertifikasi komputer seperti sertifikasi jaringan dan database bagi divisi IT dan staff untuk meningkatkan kompetensi dibidang Teknologi Informasi, sehingga seluruh staff khususnya dibagian pengeololaan sistem informasi tersertifikasi.

2. Domain BAI 4 Mengelola Ketersediaan dan Kapasistas sistem dan domain DSS 1 Mengelola Operasional. Pada domain BAI 4 dan DSS 1 yaitu sama-sama berada pada level 3 (established). Pihak perusahaan sudah melakukan pembaharuan terhadap beberapa hardware komputer di setiap staff. Penggantian perangkat komputer tersebut untuk menunjang software yang digunakan. Oleh karena itu rekomendasi yang tepat untuk menyelesaikan permaslahan diatas antara lain:

a) Meningkatkan kekampuan tenaga IT di Sub Bidang Pemutakhiran Data dan Teknologi Informasi mengenai teknologi baru yang digunakan sehingga dapat menangani gangguan jaringan lebih cepat.

b) Pihak IT harus melakukan evaluasi kinerja dan penilaian terhadap sistem untuk mecegah gangguan jaringan yang terjadi.

c) Sistem penyimpanan (database) diperbaharui ke versi yang lebih baru agar dalam pengoperasian sistem tersebut dapat optimal, baik dalam melakukan pengolahan data maupun yang lainnya. 
d) Selain penambahan server untuk penyimpanan data wajib pajak yang terus bertambah dari tahun ke tahun, Badan Pendapatan Daerah Kabupaten Badung juga perlu mempersiapkan sistem database berbasis cloud. Sistem penyimpanan data menggunakan Cloud System bertujuan untuk backup data atau duplikasi data di luar lingkungan Badan Pendapatan Daerah Kabupaten Badung untuk mengantisipasi keamanan data jika terjadi bencana.

3. Domain EDM 4 Memastikan pengptimalan sumber daya, domain BAI 9 Mengelola aset, dan domain MEA 1 tentang Monitor, Evaluasi, dan Penilaiaan kinerja dan kesesuaian. Pada domain EDM 4, BAI 9 dan MEA 1 digolongkan pada level 3 (established). Pada masalah pengelolaan aset dan optimalisasi sumber daya yang dimiliki oleh Badan Pendapatan Daerah Kabupaten Badung belum maksimal dilakukan. Akan tetapi dalam penerapan sistem sering kali adanya pemeliharaan dan pengembangan sistem yang digunakan maupun sistem external dan internal yang tidak diberitahukan langsung kepada wajib pajak sehingga berakibatkan pengguna wajib pajak secara online tidak bisa menggunakannya dan juga berdampak belumnya terverifikasi pelaporan SPTPD (Surat Pemberitahuan Pajak Daerah) secara online maupun sistem internal dan sistem extrenal. Adanya rekomendasi perbaikan untuk masalah tersebut yaitu,

a) Adanya pemberitahuan dari Badan Pendapatan Daerah Kabupaten Badung kepada setiap wajib pajak secara langsung bahwa sistem sedang ada pemeliharaan. Rekomendasi ini menjadi prioritas di karenakan menyangkut kepada konsumen yang menggunakan aplikasi dari Badan Pendapatan Daerah Kabupaten Badung.

b) Menyiapkan prosedur untuk pengecekan aset secara berkala setiap sebulan sekali agar aset yang dimiliki oleh Badan Pendapatan Daerah Kabupaten Badung dapat terjaga dengan baik. Jadi bila terjadi kehilanganatau kerusakan dapat diatasi dengan segera.

c) Pengoptimalan sumber daya khususnya pada infastruktur Teknologi Informasi, maka perlu untuk mengevaluasi atau audit jaringan computer dan keamanan sistem menggunakan standar ISO 27001, tujuannya untuk mengetahui tingkat keamanan sistem yang ada di Badan Pendapatan Daerah Kabupaten Badung. Penerapan sistem informasi baru yang dapat mengoptimalkan dan mengefisienkan kinerja. Beberapa sistem yang direkomendasikan untuk dibuat adalah sistem manajemen asset Badan Pendapatan Daerah Kabupaten Badung untuk monitoring penambahan dan penyusutan asset. Selain itu Badan Pendapatan Daerah Kabupaten Badung perlu menggunakan sistem surat menyurat untuk mempermudah/efisiensi penomoran surat otomatis, serta mencatat surat masuk untuk keperluan dokumentasi dan disposisi, sistem surat menyurat ini diharapkan memiliki fitur reminder (pengingat otomatis) yang terintegrasi dengan sms/email/whatsapp. Selain itu untuk monitoring dan evaluasi kegiatan, Badan Pendapatan Daerah Kabupaten Badung wajib memiliki sistem informasi eksekutif (dashboard) agar pimpinan maupun stakeholder dapat melihat secara langsung dan update mengenai kegiatan yang sedang berlangsung.

\section{Kesimpulan}

Berdasarkan hasil analisis dan evaluasi yang telah dilakukan, maka dapat disimpulkan sebagai berikut:

1. Tingkat kematangan tata kelola teknologi informasi berada pada level 3 (established) dengan rata-rata 3,30.

2. Untuk meningkatkan tingkat kematangan dari level 3 ke level 5 sesuai yang diharapkan, maka rekomendasi yang diajukan sebagai berikut:

a. Melakuka pelatihan secara intens oleh pihak IT di Badan Pendapatan Daerah Kabupaten Badung kepada admin yang menjalankan sistem SISMIOP (Sistem Informasi dan Manajemen Objek Pajak), sehingga resiko kesalahan dapat diminimalisasi.

b. Dibuatkan sistem yang informasi dengan user interface yang mudah digunakan (user friendly) agar dapat memudahkan staff yang bertugas dalam mengoperasikan sistem informasi di Badan Pendapatan Daerah Kabupaten Badung.

c. Melakukan evaluasi kinerja dan penilaian terhadap sistem untuk mecegah gangguang jaringan yang terjadi.

d. Membuat sistem manajemen asset pada Badan Pendapatan Daerah Kabupaten Badung untuk monitoring penambahan dan penyusutan asset.

\section{Saran}

Berdasarkan hasil penelitian ini, ada beberapa saran yang dapat diperhitungkan sebagai berikut:

1. Melakukan evaluasi, penilaian dan pengarahan terkait dengan seluruh kegiatan yang ada di Badan Pendapatan Daerah Kabupaten Badung baik evaluasi 
dalam sistem informasi yang di gunakan, maupun sumber daya yang ada di perusahaan.

2. Perlu untuk mengevaluasi atau audit jaringan komputer dan keamanan sistem menggunakan standar ISO 27001, untuk mengetahui tingkat keamanan sistem.

3. Meningkatkan tata kelola terkait domain EDM 4, APO 1, APO 7, BAI 4, BAI9, DSS 1 dan MEA 1 sesuai dengan rekomendasi.

\section{References}

[1] Mega, P. "Tata Kelola Teknlogi Informasi (IT Governance) Menggunakan Framework COIT 5 Studi Kasus: Dewan Kehormatan Penyelenggaran Pemilu (DKPP)". Skripsi Universitas Islam Negeri Syarif Hidayatullah Jakarta 2013.

[2] Chintya. "Audit Tata Kelola Teknologi Informasi Di Universitas Lampung Menggunakan Framework COBIT 5 Fokus Domain EDM (Evaluate, Direct, and Monitor)". Skripsi Universitas Lampung 2017.

[3] Guido, W., Augie, D. M. “Evaluasi Kinerja Tata Kelola TI Terhadap Sistem Informasi Starclick Framework COBIT 5 Studi Kasus: PT. Telekomunikasi Indonesia, Tbk Semarang. Vol. 02 pp. 157-166. Desember. 2016. Universitas Kristen Satya Wacana. Jawa Tengah 2016.

[4] Agus, P. U., Novita, M. “Analisis Tata Kelola Teknologi Informasi (IT Governance) pada Bidang Akademik dengan COBIT Framework Studi Kasus: Universitas Stikubank Semarang". Vol. 16 pp 139-149. Juli. 2011. Universitas Stikubank Semarang 2011.

[5] Amalia, R. R. "Audit Sistem Informasi Akademik UIN Sunan Kalijaga Yogyakarta Menggunakan COBIT Framework pada Domain Deliver and Support". Skripsi Universitas Islam Negeri Sunan Kalijaga Yogyakarta 2014.

[6] Raditya, I.G.L.A. "Evaluasi Tata Kelola Teknologi Informasi Berbasis Cobit 5 Dalam Pelayanan Sistem Informasi Akademik Di Universitas Pendidikan Ganesha". Tesis Universitas Atmajaya. Yogyakarta 2015.

[7] Swastika, A, Raditya. "Audit Sistem Informasi dan Tata Kelola Teknologi Informasi: Implementasi dan Studi Kasus". Yogyakarta: Andi 2016.

[8] Utami, dkk. "Audit Capability EAM (Enterprise Assets Management) menggunakan COBIT 5 dan ISO 55002 pada Perusahaan Kelistrikan Negara". Vol. 4 pp. 195-204. Desember 2016. Universitas Udayana 2016.

[9] ISACA COBIT 5: Enabling Processes Governance and Management Practices. United States of America: ISACA \& ITGI 2012.

[10] ISACA. Control Objective for Information and Related Technology. Retrieved Juni, from ISACA:
http://www.isaca.org/COBIT/Pages/default.aspx 2017.

[11] ITGI. IT Governance Institute. Retrieved Juni from www.itgi.org/About IT Governance 2017.

[12] Iskandar. "Metodologi Penelitian Pendidikan dan Sosial (Kualitatif dan Kuantitatif)". Jakarta: GP Press 2008.

[13] Jogiyanto, H. M., \& Abdilah, W. "Sistem Tatakelola Teknologi Informasi". Yogyakarta: Andi Offset 2011.

Program Studi Teknik Informatika

Universitas Prima Indonesia (UNPRI) Medan 